\title{
Sickle cell disease and the adherence to guidelines for the use of blood transfusions in Duhok, Kurdistan, Iraq
}

Abstract
Background and objective: One of the important health problems in Duhok city , Iraqi

Background and objective: One of the important health problems in Duhok city, Iraqi Kurdistan Region, is sickle cell disease. Blood transfusion remains a significant therapeutic intervention in patients with sickle cell disease that reduces complications related to vaso-occlusions. This study aimed to assess compliance to guidelines for the use of blood transfusionsin Duhok, Kurdistan, Iraq.

Methods: This is a cross-sectional study that included 135 patients with sickle cell disease registered at Jeen center of pediatric hematological diseases in Duhok, Kurdistan, Iraq. Between April $1^{\text {st }}$ and July $31^{\text {st }}, 2019,205$ medical visits of sickle cell disease were registered. Every patient was evaluated to record the clinical setting and explanations behind visiting and indications for transfusion.

Results: Of 135 patients,65.9\% had sickle cell anemia (HbSS disease), 33.3\% had sickle beta thalassemia, and one patient $(0.7 \%)$ had Sickle/D disease. A total of 205 medical visits of sickle cell disease were registered with 84 blood transfusion decisions. The most common indicated guideline reasons for transfusion were symptomatic anemia and acute hemolytic crisis with a drop of hemoglobin $>2 \mathrm{~g} / \mathrm{dl}$ below steady state hemoglobin and severe painful crisis only accounted for $38.1 \%$.

Conclusion: In this study of patients with sickle cell disease, most blood transfusions were not indicated according to the transfusion guidelines (British Committee for Standards in Haematology - BCSH, 2017).

Keywords: Transfusion guidelines for sickle cell disease (BCSH 2017); Sickle cell disease; Iraq.

\section{Introduction}

Sickle cell disease is a hemoglobin disorder inherited in an autosomal recessive pattern, hemoglobin $S$ formed due to the substitution of valine for glutamic acid at position 6 of $\beta$-globin chain of hemoglobin. When hemoglobin $S$ is deoxygenated, it undergoes polymerization, leading to a phenotype characterized by a chronic hemolytic process, often heightened by various crises, particularly vaso-occlusive ones, resulting in multiple organ damages. ${ }^{1}$ An important therapeutic procedure used for patients with sickle cell disease is blood transfusion. There are some clinical conditions in which sickle cell disease patients need red blood cells transfusion (RCT). In other conditions, the indication is doubtful or controversial. Transfusion is used on either a chronic or an episodic basis in the management of sickle cell disease. Chronic transfusion therapy is used for sickle cell disease patients with a history of strokes as a preventative approach to reduce its reoccurrence. Episodic transfusions are typically used in a patient who has already developed a serious complication of sickle cell disease like acute management of stroke or applied to reduce the likelihood of developing a complication such as hepatic sequestration or acute splenic. In recent times, chronic transfusion has been offered

${ }^{1}$ Department of Hematology, Azadi Teaching Hospital, Duhok, I raq.

2 Department of Pathology, College of Medicine, University of Duhok, Duhok, I raq

* Correspondence: dr_adnananwar@uod.ac 
to those patients with signs of cerebrovascular disease to avert the first occurrence of stroke. ${ }^{2,3}$ The United States America Food and Drug Administration (FDA) approves the use of hydroxycarbamide for use in adults with sickle cell disease. ${ }^{4}$ In clinical practice, Hydroxycarbamide is most commonly used as fetal hemoglobin ( $\mathrm{HbF})$ modulator. ${ }^{5}$ Furthermore, its use in children has been demonstrated to be beneficial by several studies. ${ }^{6}$ Hydroxyurea is the only drug to date that can reduce the number of episodes of acute chest syndrome and reduce the severity and number of pain crises and mortality. ${ }^{7}$ The indications for blood transfusion in sickle cell disease differ and should be taken on a case-bycase basis, weighing the risks and benefits of undertaking such treatment. In some patients, red cell transfusion would be strongly recommended, while others would not be clinically proven or could even be controversial. The indications can be broadly categorized into conditions in which rectification of anemia is the main objective and those where the decrease of sickle hemoglobin ( $\mathrm{HbS}$ ) may be more suitable. In both categories, transfusion is accomplished either acutely, as part of the control of an acute complication of sickle cell disease, or electively for the prevention or management of disease complications. Elective transfusions may be one-off (e.g., preoperative) or be part of a long term transfusion program with proper experience. ${ }^{8}$ The management of sickle cell patients can be divided as such: 1) Analgesia and blood transfusions which can be used for long and short term care, 2) therapies that as targeted and specific such as hydroxyurea that aid in the management and prevention of complications, 3) gene replacement therapy could be a form of curative treatment as well as different forms of hematopoietic stem cell transplantation 4) and genetic counseling for families as a preventative approach. ${ }^{9-13}$ To our acquaintance, there are no studies addressing sickle cell disease and the adherence to guidelines for the use of blood transfusions in Iraqi Kurds with sickle cell disease. Because of the importance of this valuation and its possible influence on patients' management and wellbeing, the current study was instigated in a single center in Duhok, Kurdistan, Iraq. This study aimed to assess compliance to guidelines for the use of blood transfusions in sickle cell disease in Duhok, Kurdistan - Iraq.

\section{Methods}

This study is cross-sectional, comprising 135 patients with sickle cell disease listed at Jeen center, Thalassemia center in Duhok, Kurdistan. Between April $1^{\text {st }}$ and July $31^{\text {st }}, 2019,205$ medical visits of sickle cell disease were registered with 84 blood transfusion decisions. We reviewed each patient individually and assessed clinically and the reason for transfusion. The subsequent were documented; gender, age, type of sickle cell disease, hemoglobin level at the time of transfusion, baseline hemoglobin, total bilirubin, reticulocyte count, GPT, Serum ferritin, high performance liquid chromatography (HPLC) using Beta short program on BioRad D-10 instrument (BioRad, USA), the reason for transfusion and the number of units transfused. Included patients were checked for any medications received, including hydroxyurea and its duration. The records were reviewed, and patient history was taken to focus mainly on the sickle cell features. The latter include the number of painful episodes in the previous 12 months, the number of transfusions in the previous 12 months, number of hospitalizations in the previous 12 months. The transfusion guidelines for sickle cell disease (BCSH 2017) were used as a reference for determining the adherence to the guideline of blood transfusions in sickle cell disease. ${ }^{8}$ The Statistical Package for the Social Sciences (SPSS version 20) software was used for all statistical analyses. Two tailed 
independent t-test and Pearson correlation, as required, were used. A $P$ value of $<0.05$ was considered significant. The research ethics committees at the Kurdistan Board of Medical Specialties and the Directorate of Health approved this study. Informed consent was obtained from all participants or their legal guardians.

\section{Results}

This study included 135 patients with a mean age of 17.68 (SD 10.82) years, and comprised 69 females and 66 males. The study group encompassed 78 children and 57 adults. Most of the patients $(65.9 \%)$ had sickle cell anemia (SS), while 45 patients $(33.3 \%)$ had sickle beta thalassemia, and only one patient was diagnosed with sickle/D disease. The negative family history for hemoglobinopathy constituted $45(33.3 \%)$ patients. About half of the patients $(48.15 \%)$ were receiving hydroxyurea, as shown in Table 1 . The mean \pm standard deviation of patients' age, age at diagnosis, $\mathrm{Hb}$, Retics, steady state $\mathrm{Hb}$, and serum ferritin was $17.68 \pm 10.82, \quad 26.08 \pm 31.5, \quad 8.06 \pm 1.47$, $12.98 \pm 6.07,8.88 \pm 0.93$, and $1574.13 \pm 2420$, respectively. Table 2 shows some hematological parameters according to blood transfusion. The steady state $\mathrm{Hb}$, $\mathrm{Hb}, \mathrm{HbS}$, and $\mathrm{HbF}$ were significantly lower in patients receiving blood transfusions, while Retics count and serum ferritin were significantly higher in patients receiving blood transfusions. Figure 1 outlines blood transfusions events by indications in sickle cell disease. The main causes for blood transfusion were vaso-occlusive pain, hemolytic crisis, avascular necrosis of hip joint and hemoglobin bellow 7 g/dl constituting 32 (38.1\%), 14 (16.7\%), $12(14.3 \%$, (and $12(14.3 \%)$ transfusion events, respectively. Figure 2 shows adherence to guidelines of blood transfusion in patients with sickle cell disease. Only 32 of $84(38.1 \%)$ of transfusion events met the transfusion guidelines for sickle cell disease (BCSH 2017).

Table 1: Demographic data with some laboratory data for patients with sickle cell disease.

\begin{tabular}{|c|c|c|}
\hline Variable & & No = $135(\%)$ \\
\hline \multirow[t]{2}{*}{ Gender } & Male & $66(48.9)$ \\
\hline & Female & $69(51.1)$ \\
\hline \multirow[t]{2}{*}{ Age } & $<18$ years & $78(57.7)$ \\
\hline & $\geq 18$ years & $57(42.2)$ \\
\hline \multirow[t]{3}{*}{ Diagnosis } & Sickle cell anemia & $89(65.9)$ \\
\hline & Sickle beta Thalassemia & $45(33.3)$ \\
\hline & Sickle/ D disease & $1(0.7)$ \\
\hline \multirow[t]{4}{*}{ No. of hospitalization in the previous 12 months } & 0 & $27(20)$ \\
\hline & 1 & $17(12.6)$ \\
\hline & $2-3$ & $26(19.3)$ \\
\hline & $>3$ & $65(48.1)$ \\
\hline \multirow[t]{5}{*}{ No. of transfusion in the previous 12 months } & 0 & $59(43.7)$ \\
\hline & 1 & $10(7.4)$ \\
\hline & $2-3$ & $23(17)$ \\
\hline & $>3$ & $43(31.9)$ \\
\hline & Mean \pm SD & Minimum - Maximum \\
\hline Age (years) & $17.68 \pm 10.82$ & $2-49$ \\
\hline Age at diagnosis (months) & $26.08 \pm 31.5$ & $1-144$ \\
\hline $\mathrm{Hb}$ & $8.06 \pm 1.47$ & $5-11$ \\
\hline Retics (\%) & $12.98 \pm 6.07$ & $2-45$ \\
\hline Steady stateHb & $8.88 \pm 0.93$ & $7-11$ \\
\hline Serum Ferritin (ng/ml) & $1574.13 \pm 2420$ & $4-12000$ \\
\hline
\end{tabular}


Sickle cell disease and the adherence to guidelines ....

Zanco J. Med. Sci., Vol. 25, No. (1), April, 2021

https:/ / doi.org/ 10.15218/ zjms.2021.011

Table 2: Some hematological parameters according to blood transfusions.

\begin{tabular}{lccc}
\hline Parameters & $\begin{array}{c}\text { Not receive blood transfusion } \\
\text { (No: 83) } \\
\text { Mean } \pm \text { SD }\end{array}$ & $\begin{array}{c}\text { Receive blood transfusion } \\
\text { (No: } \mathbf{5 2}) \\
\text { Mean } \pm \text { SD }\end{array}$ & $\boldsymbol{P}$ value \\
\hline Steady state Hb & $9.14 \pm 0.857$ & $8.46 \pm 0.917$ & $<0.001$ \\
Hb & $8.92 \pm 1.027$ & $6.69 \pm 0.961$ & $<0.001$ \\
Retics & $11.89 \pm 4.864$ & $14.71 \pm 7.344$ & 0.016 \\
Ferritin & $1101.83 \pm 1657.933$ & $2328 \pm 3167.1$ & 0.012 \\
GPT & $25.98 \pm 14.613$ & $28.54 \pm 18.921$ & 0.407 \\
TSB & $2.82 \pm 1.914$ & $2.75 \pm 2.566$ & 0.867 \\
HbS & $67.17 \pm 13.663$ & $58.38 \pm 16.960$ & 0.002 \\
HbF & $18.57 \pm 11.222$ & $12.27 \pm 8.310$ & $<0.001$ \\
\hline
\end{tabular}

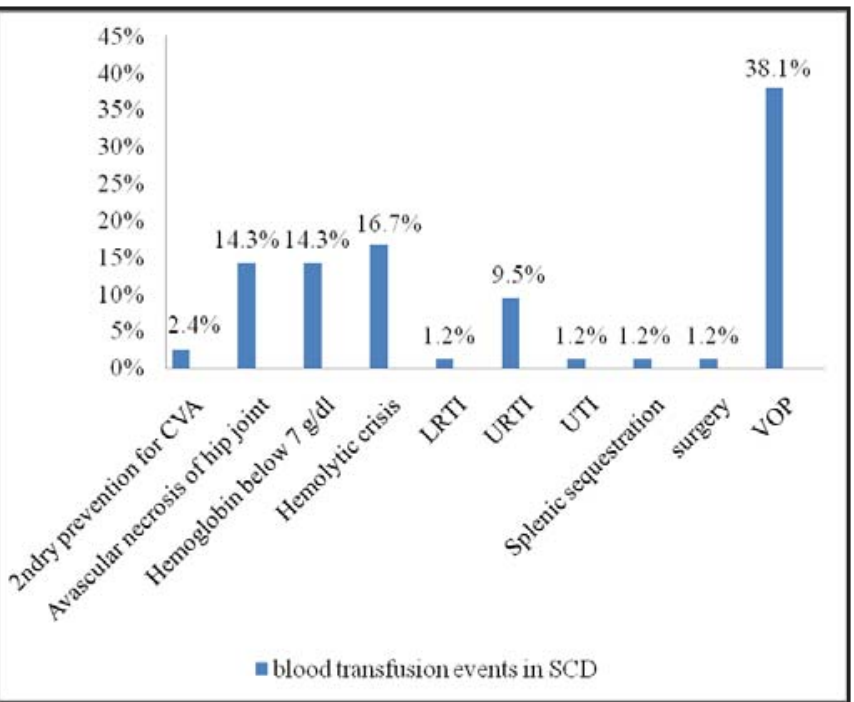

Figure 1: Blood transfusions events by indication in sickle cell disease. CVA, cerebrovascular accident; LRTI, lower respiratory tract infection; URTI, upper respiratory infection; UTI, urinary tract infection; VOP, vaso-occlusive pain.

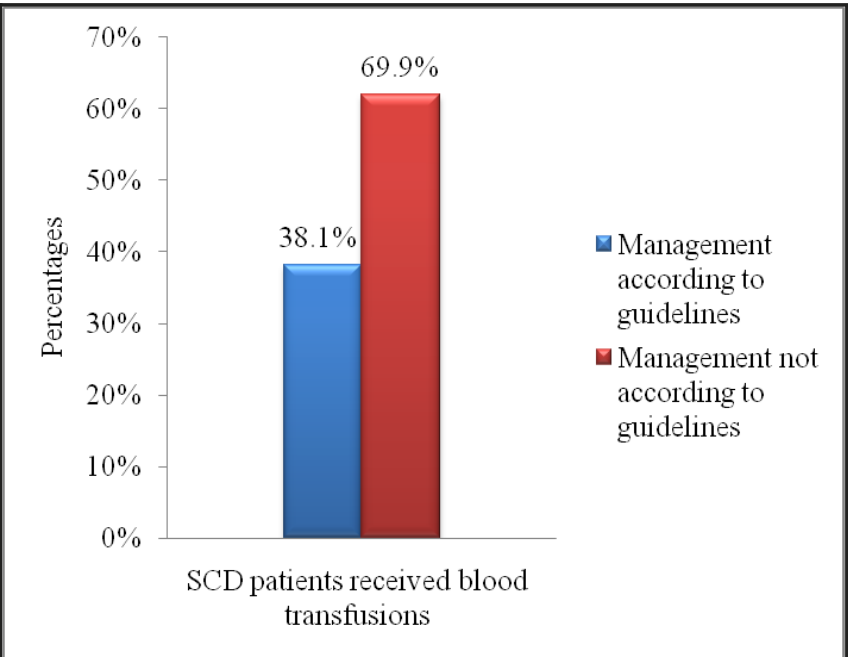

Figure 2: Adherence to guidelines of blood transfusion in patients with sickle cell disease. 


\section{Discussion}

Due to the nature of this disease, sickle cell disease may affect multiple body organs, which can lead to a risk of developing life-threatening illnesses. ${ }^{9,10,14-17}$ Thus, caring for such patients would require a multidisciplinary approach. ${ }^{9,10,17}$ The most common cause for hospital admission for sickle cell disease in the current study was vaso-occlusive pain episode, which is similar to that reported by Kelly et al. ${ }^{18}$ and the result from Saudi Arabia. ${ }^{19}$ About $38.1 \%$ of transfusion events were due to vaso-occlusive pain; most of them did not meet transfusion guidelines. According to published recommendations, patients who have acute painful episodes do not qualify for a transfusion if they have no other complications. ${ }^{20-22}$ In adherence to the published recommendations, practitioners would greatly benefit from this information as acute painful episodes would not indicate intervention as these episodes are a common complication of sickle cell disease. The sickle cell disease severity is measured by the frequency of sickle cell painful crises; the hospital admission $\geq 3$ times a year due to vaso-occlusive crises have an increased early death risk. ${ }^{23}$ High readmission rates and longer hospital stays are also associated with higher mortality. ${ }^{24,25}$ Patients with recurrent painful crises might benefit from long term transfusions. According to the SIT trial, the number of painful episodes was reduced by blood transfusion significantly. ${ }^{26}$ However, hydroxyurea is highly effective in reducing the rate of painful crises and ACS in both adults and children ${ }^{27-29}$ and improves survival. ${ }^{30}$ Thus, transfusion is kept for those who do not respond or in whom hydroxyurea is contraindicated, and hydroxyurea is the first line treatment for patients with frequent vaso-occlusive crises. Transfusion events due to established avascular necrosis of the hip joint in this study were $14.3 \%$. Blood transfusion in the controlled trial for silent cerebral infarcts in sickle cell anemia decreased the incidence of symptomatic avascular necrosis (randomized SIT trial), ${ }^{26}$ but its effectiveness in patients with the established disease has not been confirmed in randomized SIT trials. ${ }^{8}$ In the current study, $16.7 \%$ of transfusion events were due to hemolytic crisis, and most of them met the transfusion guidelines. The steady state is relatively stable most of the time and interrupted intermittently by hemolytic crises, which could be acute and fatal. ${ }^{31}$ Our study shows that transfusion events during follow up were 12 (14.3\%) events. The indication of transfusion was hemoglobin level $<7 \mathrm{~g} / \mathrm{dl}$. Most of them did not meet transfusion guidelines because they already had low steady state hemoglobin. a similar result was reported by Park et al..$^{32}$ It should be noted that the low steady state $\mathrm{Hb}$ in sickle cell disease is the result of the low oxygen affinity of hemoglobin $S$ and is therefore not in itself an indication or transfusion. ${ }^{8}$ Our study reveals that out of 84 transfusion events, only $32(38 \%)$ events met transfusion guidelines which are similar to another study done by Park et al., only $34.5 \%$ of transfusion events met expert panel recommendations. ${ }^{32}$ It seems to be that a significant number of avoidable transfusions in sickle cell disease patients were administered. Low adherence level was encountered in vaso-occlusive pain, avascular necrosis of hip, and hemoglobin below $7 \mathrm{~g} / \mathrm{dl}$. Many uncomplicated painful crises received a transfusion, which is deviated from transfusion guidelines. A hemoglobin level below $7 \mathrm{~g} / \mathrm{dl}$ is regarded as a blood transfusion indication. If there is a big drop in $\mathrm{Hb}$ from baseline (e.g., $>20 \mathrm{~g} / \mathrm{l}$ or to $\mathrm{Hb}<50 \mathrm{~g} / \mathrm{l}),{ }^{8}$ a blood transfusion should be considered, but it is not recommended in patients with uncomplicated painful crises. Our study has a few limitations, including being a cross-sectional, observational study, and the number of patients in the study was low. However, to decrease the complications of sickle cell disease, more effort is needed to improve adherence to the blood transfusion guidelines. 


\section{Conclusion}

In this study of patients with sickle cell disease, most blood transfusions were not indicated according to the transfusion guidelines (BCSH 2017). We aim to increase adherence to the set guidelines for care givers and create an educational program that would clearly decipher between patients with sickle cell disease who would benefit from a blood transfusion from the ones who would not.

\section{Competing interests}

The authors declare no competing interests.

\section{References}

1. Stuart MJ, Nagel RL. Sickle-cell disease. Lancet 2004; 364(9442):1343-6.

2. Ohene-Frempong K. Indications for red cell transfusion in sickle cell disease. J Hematol Oncol 2001; 38(S1):5-13.

3. Mehta S, Afenyi-Annan A, Byrns P, Lottenberg R. Opportunities to improve outcomes in sickle cell disease. Am Fam Physician 2006; 74:30310.

4. Strouse J J, Heeney M M. Hydroxyurea for the treatment of sickle cell disease: efficacy, barriers, toxicity, and management in children. Pediatr Blood Cancer 2012; 59(2):365-71.

5. Eissa A, Markous R, Yahya N, Al-Allawi N. Hemoglobin $F$ modulation in sickle cell disease: Experience in a single center in Iraqi Kurdistan. J Appl Hematol 2016; 7:85.

6. Halsey C, Roberts IAG. The role of hydroxyurea in sickle cell disease. $\mathrm{Br} J$ Haematol 2003; 120(2):177-86.

7. Kohne E. Hemoglobinopathies: clinical manifestations, diagnosis, and treatment. Dtsch Arztebl Int 2011; 108(31-32):532-40.

8. Davis BA, Allard S, Qureshi A, Porter JB, Pancham S, Win N, et al. Guidelines on red cell transfusion in sickle cell disease Part II: indications for transfusion. $\mathrm{Br} \mathrm{J}$ Haematol 2017; 176(2):192-9.

9. Kaur M, Dangi CBS, Singh M. An overview on sickle cell disease profile. Asian J Pharm Clin Res 2013; 6(Suppl 1):25-37.

10. Bender MA, Hobbs W. Sickle cell disease. 2003 Sep 15 [updated 2012 May 17]. In: Pagon RA, Adam MP, Ardinger HH, Bird TD, Dolan CR, Fong CT, et al., editors. Gene Reviews. Seattle (WA): University of Washington, Seattle; 19932014.

11. Field JJ, Vichinsky E. Overview of the management and prognosis of sickle cell disease. $31^{\text {st }}$ ed. United States: Uptodate; 2014; 122-3.
12. Townes TM. Gene replacement therapy for sickle cell disease and other blood disorders. Hematology 2008; 2008(1):193-6.

13. Shenoy S. Hematopoietic stem cell transplantation for sickle cell disease: Current practice and emerging trends. Hematology 2011; 273-9.

14. Driss A, Asare KO, Hibbert JM, Gee BE, Adamkiewicz TV, Stiles JK. Sickle cell disease in the post genomic era: A monogenic disease with a polygenic phenotype. Genomics Insights 2009; 23-8.

15. Schnog J, Duits AJ, Muskiet F, Tencate H, Rojer RA, Brandjes D. Sickle cell disease a general overview. Neth J Med 2004; 62:36474.

16. Elliott PV, Michael RD, Jennifer ST. Overview of the clinical manifestations of sickle cell diease. Uptodate 2014.

17. Ballas SK, Kesen MR, Goldberg MF, Lutty GA, Dampier C, Osunkwo I, et al. Beyond the definitions of the phenotypic complications of sickle cell disease: an update on management. Scientific World Journal 2012; 949535.

18. Kelly S, Deng X, Hoppe C, Styles L. A pilot randomized trial of red blood cell transfusion for acute treatment of vaso-occlusive pain episodes in sickle cell anaemia. $\mathrm{Br} \mathrm{J}$ Haematol 2015; 171(2):288-90.

19. Al Jaouni S, Almuhayawi $M$, Halawa $T$, Mehayawi M. Treatment adherence and quality of life outcomes in patients with sickle cell disease. Saudi Med J 2013; 34:261-5.

20. Josephson CD, Su LL, Hillyer KL, Hillyer CD. Transfusion in the Patient With Sickle Cell Disease: A Critical Review of the Literature and Transfusion Guidelines. Transfusion Med Rev 2007; 21(2):118-33

21. Lionnet $F$, Arlet JB, Bartolucci $P$, Habibi $A$ Ribeil JA, Stankovic K. Recommandations pratiques de prise en charge de la drépanocytose de l'adulte. La Revu. de Méd Inte 2009; 30(S1):162-223.

22. Telen M. Principles and problems of transfusion in sickle cell disease. J Hematol Oncol 2001; 38:315-23.

23. Niscola $P$, Sorrentino $F$, Scaramucci L, De Fabritiis $\mathrm{P}$, Cianciulli P. Pain syndromes in sickle cell disease: An update. Pain Medicine 2009; 10(3):470-8.

24. Houston-Yu P, Rana SR, Beyer B, Castro O. Frequent and prolonged hospitalizations: A risk factor for early mortality in sickle cell disease patients. Am J Hematol 2003; 72(3):201-3.

25. Ballas S K, Lusardi M. Hospital readmission for adult acute sickle cell painful episodes: frequency, etiology, and prognostic significance. Am J Hematol 2005; 79(1):17-25.

26. DeBaun MR, Gordon M, McKinstry R C, Noetzel MJ, White DA, Sarnaik SA, et al. Controlled trial of transfusions for silent cerebral infarcts in sickle 
27. Steinberg MH, McCarthy WF, Castro O, Ballas SK, Armstrong FD, Smith W, et al. The risks and benefits of long-term use of hydroxyurea in sickle cell anemia: A 17.5 year follow-up. Am J Hematol 2010; 85(6):403-8.

28. Thornburg C D, Calatroni A, Telen M, Kemper A R. Adherence to hydroxyurea therapy in children with sickle cell anemia. J Pediatr 2010; 156 (3):415-9.

29. Al Hawsawi ZM, Ahmed Turkistani W. Effect of hydroxyurea in children with sickle cell disease in Saudi Arabia. J Taibah Univ Sci 2008; 3(2):129_ 34.

30. Steinberg $\mathrm{MH}$, Barton $\mathrm{F}$, Castro $\mathrm{O}$, Pegelow $\mathrm{CH}$, Ballas SK, Kutlar A, et al. Effect of hydroxyurea on mortality and morbidity in adult sickle cell anemia risks and benefits up to 9 years of treatment. JAMA 2003; 289(13):1645-51.

31. Akinbami A, Dosunmu A, Adediran A, Oshinaike $O$, Phillip A, Vincent $O$, et al. Steady state hemoglobin concentration and packed cell volume in homozygous sickle cell disease patients in Lagos, Nigeria. Caspian J Intern Med 2012; 3(2):405-9.

32. Park DD, Jacob DG, Adedemola A, Mowatt K, Persaud T, Tipirneni A, et al. Sickle cell disease and the adherence to guidelines for use of blood transfusions. Blood 2017; 130:4652. 